\title{
Control of Microorganisms
}

The control of microorganisms is one of the major concerns of food microbiologists. This control is needed to retard or prevent spoilage and to reduce or eliminate health hazards associated with foods. The control of contaminants also aids in obtaining better results when specific microorganisms or enzymes are used in food processing.

Four basic systems are used to aid in the control of microorganisms in foods. These are (1) prevent contamination (asepsis); (2) remove contaminants; (3) inhibit growth; and (4) destroy contaminants.

In most food products, two or more of these systems are used to control the microbial level. Preventing contamination is practiced for all foods, but since contamination will still occur, other safeguards are needed.

Besides controlling the microorganisms, foods must be protected from reactions that are catalyzed by inherent enzymes, from chemical degradation such as fat oxidation, loss of nutrients, and from the destruction by pests, such as insects and rodents. There are various chemicals and procedures that will control microorganisms and pests but cannot be used for foods. This is because the food must be safe for consumption, be of acceptable organoleptic quality, and have good nutritional value.

Although the control of microorganisms in food is usually relegated to the food processor, everyone involved in the production, processing, handling, warehousing, retailing, preparation, and serving should be involved in the control process as well as in maintaining a safe and nutritious food supply.

The need for this overall effort is evident from the fact that only a few outbreaks of foodborne illness are caused by problems at the processing level. Most of the outbreaks are caused by mishandling and contamination of foods at foodservice establishments or in the home.

In some cases, we assume that a food will be handled and used in a particular manner; but this assumption may not always be correct. For example, we assume that people will cook meat before eating it. However, a series of outbreaks of salmonellosis revealed that some people thought that eating raw hamburger would make them healthy, strong, and vigorous. Because of such misuse of foods by some people, it is necessary to take precautions beyond the normal processing requirements. A 
food microbiologist must be aware of all aspects of a food, from production to consumption.

A primary function of food processing is the preservation of foods. This preservation ranges from short periods of a few days or weeks to long terms of a year or more. Preservation by the removal, inhibition, or destruction of microorganisms is easier and the results are more satisfactory when the original microbial index of the food is low. Keeping the contamination low by sanitary means is very important.

\section{CONTROL BY ASEPSIS}

If all of the microorganisms in a food were either useful or inert, we would have no concern about them. Unfortunately, the spoilage and health hazard types are quite prevalent. Generally, the higher the microbial load, the greater the possibility that undesirable types are included. The exceptions are foods in which specific microorganisms are grown to produce desirable products and a high level of the useful microorganism is needed.

It is much easier to inhibit or destroy low numbers of microorganisms than high numbers. A food with a low microbial load will generally have a longer shelf life than a food with a high microbial level. The shelf life is the time after packaging during which a food maintains its best quality if it is stored under proper conditions of humidity and temperature.

Because microorganisms are ubiquitous, it is impossible to keep them from contaminating food. However, we can reduce contamination by controlling the potential sources of microorganisms.

The control of contamination is referred to as sanitation. Sanitation may be defined as a modification of the environment in such a way that maximum health, comfort, safety, and well-being are ensured for people. The sanitation involved in the food industry is only a small part of overall sanitation.

The control of the microbial quality of food must begin with the production and harvesting of food. Then it must carry over to the processor and on to the ultimate consumer.

\section{Production and Harvesting}

The raw materials used by the food processor affect the quality of the finished product. To have adequate supplies of high-quality raw materials with acceptable microbial loads, the food processor must work closely with the producer or become the producer. In some cases, a food processor who is also the producer seems to be the best method. As a result, we 
now have companies that own or control food-producing and -processing systems. By owning a system, the company can integrate all of the processes to end up with a uniform, high-quality product.

With many foods, the processor must rely on the producer to deliver an acceptable raw material. Some ingredients are obtained from foreign countries where the level of sanitation is different from that in the United States. Hence, processors sometimes have to work with raw materials that are produced in areas beyond their control. Sometimes a visit to the foreign supply areas will help in obtaining more acceptable products.

When the raw materials are obtained from local areas, the processor can usually visit the sources of supply, make evaluations, and suggest procedures that will improve the quality. Sometimes the processor obtains help from local, state, and federal regulatory agencies that inspect the producing areas.

MILK. Many years ago, the occurrence of epidemics of various diseases caused by the consumption of tainted milk caused health authorities to decide that milk production should be regulated. To help control the spread of tuberculosis, cows were tested and reactors eliminated. From this beginning, many regulations and codes of operations have been devised to control the production and handling of milk at the farm. No other commodity is produced with as much regulation as grade A milk. As a result, tuberculosis and brucellosis in milk are controlled. At present, the main infectious problem at the farm is mastitis.

Besides the health of the dairy cow, standards have been developed for the housing and milking areas so that they can be maintained in a satisfactory manner. There are requirements for the equipment used to obtain, handle, and store the milk, and for the equipment to be properly cleaned, sanitized, and maintained (Guterbock, Blackmer, and Duffy 1984; Stone, Myhr, and Davie 1983). Grade A milk must be cooled to $10^{\circ} \mathrm{C}$ or less within two hours after milking to maintain the quality. The requirements are more stringent for the production of grade A milk than for the manufacturing of grade milk. This latter milk is used in various dairy products other than liquid milk.

Insect and rodent control are needed at the farm level as well as at the processing level. Only approved insecticides can be used in dairy barns or around other food products. Removing potential breeding places helps control insects and rodents.

ANIMAL PRODUCTION. Healthy, disease-free animals should be maintained in a relatively clean, disease-free environment. Modern husbandry practices have tended to increase rather than decrease infections in domestic animals. The practice of crowding animals into feedlots, 
broiler houses, laying houses, and holding pens increases the potential for spreading diseases, including salmonellosis. Sanitation of all animal quarters on the farm may help, but will not prevent, infection.

With meat-type chickens (broilers), flocks that are Salmonella-free tend to result in carcasses that are Salmonella-free. When salmonellae are isolated from birds prior to slaughter, the carcasses tend to contain these organisms.

The transportation of animals to market or from one farm to another causes stress, and animals held in dirty pens until slaughter shed salmonellae at a higher rate than on the farm. This indicates that stress induces shedding of organisms already present in the intestinal tract, or it makes the animals very susceptible to Salmonella infection, or both. One solution may be to hold animals at the farm and then move them into clean, uncrowded conveyances to the slaughterhouse for immediate slaughter.

One source of contamination of carcasses during slaughter is of fecal origin. Withdrawal of feed and water 8 to $10 \mathrm{hr}$ before slaughter reduces the fecal content of chickens and might reduce the potential contamination of the carcasses.

SHELL EGGS. Regardless of whether laying hens are housed on the floor or in cages, it is desirable to keep the egg shells clean. The incidence of spoilage is much greater in dirty eggs than in clean eggs, whether the shell is washed or not. When eggs are washed, the temperature of the wash water should be $20^{\circ} \mathrm{C}$ higher than the temperature of the egg and an approved germicide should be added to the cleaning solution. The addition of a germicide tends to reduce spoilage of the washed eggs during storage. Only odorless, nontoxic cleaner-sanitizers should be used for washing and sanitizing egg shells.

FRUITS AND VEGETABLES. The production of quality plant products starts with quality plant varieties and seeds. The disease resistance and the amount and quality of food produced are important consider. ations for the selection of plant varieties.

The World Health Organization (WHO 1969) recommended several hygienic practices for fruits and vegetables. The environmental sanitation during growing included sanitary disposal of human and animal wastes, sanitary quality of irrigation water, and control of animals, pests, and diseases. The sanitary harvesting aspects include the equipment and containers, which should be cleaned and maintained and not be a source of microorganisms. Unfit produce should be segregated and disposed of in a satisfactory manner. The product should be protected from contamination by animals, insects, birds, chemicals, or microorganisms.

The transportation of produce should be done in conveyances that 
can be cleaned and not be a source of contamination. All handling should be done with care and, if needed, refrigeration or ice of sanitary quality should be used.

The contamination of plant products by soils is important to the food processor, since soils contain bacterial spores, including those of Clostridium botulinum. Bacterial spores are resistant to various sanitizing agents, as well as food-preservation treatments. Hence, it would be a definite advantage to the processor if spores could be kept out of the raw materials.

SEAFOODS. Seafoods are contaminated by the environment in which they grow, as well as during harvesting and transportation to the processing plant.

The main problem of contamination during growth involves the bivalve mollusks, such as oysters, clams, and mussels. They grow in estuaries or protected coastal waters. These are also the most convenient places for the disposal of sewage and other wastes of coastal communities. The mollusks obtain nourishment by pumping water through a complex system of gills that filter and concentrate food, such as bacteria and marine organisms. With the dumping of sewage, the bacteria may include potential pathogens. With oysters and clams, the entire animal, including the intestinal tract and its contents, is consumed, frequently raw or after superficial heating. If the bivalves have consumed enteric pathogens, they can serve as vehicles for organisms that cause foodborne illness.

Due to a series of illnesses culminating in a major typhoid fever epidemic in 1924 from the consumption of contaminated oysters, a voluntary cooperative program for the certification of interstate shellfish shippers was established in 1925 by the U.S. Public Health Service. The program is now known as the National Shellfish Sanitation Program (NSSP). The coastal states adopt laws, make sanitary and microbial surveys of shellfish-growing areas, delineate and patrol restricted areas, prevent illegal harvesting, inspect shellfish-processing plants, and conduct other activities needed to ensure that shellfish are grown, harvested, and processed in a sanitary manner.

The FDA administers the NSSP at the federal level and is responsible for evaluation of state and foreign programs, standards development, research, and training.

The survey of the growing areas has three parts: (1) the area is sufficiently removed from major sources of contamination so that shellfish are not subject to fecal contamination; (2) the area is free from pollution by potentially harmful industrial wastes; and (3) the median coliform level does not exceed $70 / 100 \mathrm{ml}$ of water and not more than 10 percent of the samples exceed $230 / 100 \mathrm{ml}$ for a five-tube MPN, or $333 / 100 \mathrm{ml}$ for 
a three-tube MPN. In 1974, the FDA proposed that the coliform standard be changed to fecal coliforms as follows: The median fecal coliform MPN value shall not exceed $14 / 100 \mathrm{ml}$ of sample, and not more than 10 percent of the samples shall exceed 43 for a five-tube, or 49 for a three-tube, MPN test (Hunt 1977).

Even with safe coliform levels, occasional outbreaks of foodborne illness have occurred after the consumption of contaminated shellfish reportedly harvested from approved areas. Vibrio cholerae was detected in estuarine-type waters even when coliforms were not detected (Guthrie and Scovill 1984; Hood and Ness 1982), and there was no strong linear correlation between $V$. cholerae and $E$. coli or fecal coliforms (Hood et al. 1983). Also, there does not seem to be a relationship between safe water and the presence of enteric viruses (Gerba et al. 1980; Vaughn and Landry 1984). Although there are problems, Larkin and Hunt (1982) stated that the shellfish control programs are working reasonably well and that there is no guarantee that raw shellfish will be free of diseaseproducing organisms or toxic materials. However, Madden, Buller, and McDowell (1986) suggested using Clostridium perfringens as the indicator organism for contaminated shellfish.

In one study, researchers found that fish, as caught, have low bacterial loads (Huss et al. 1974). The hygienic standards on board the ship determined the level of contamination of the fish. To reduce the growth rate of the bacteria, proper refrigeration, icing, or freezing must be used. The fish should be processed as soon as possible after catching. Some ships have processing systems on board. In these cases, seawater is used to wash and process the fish. If not treated with chlorine, this water may serve as a source of microorganisms. The sanitary conditions of the working areas and equipment, and the health and hygiene of workers on the ship should be the same as in processing plants on land.

\section{Processing}

If care is taken to produce and deliver a high-quality product to the processing plant, it is the duty of the processor to maintain the quality at a high level.

The U.S. Food, Drug and Cosmetic Act of 1968 states: "A food shall be deemed to be adulterated if it contains any poisonous or deleterious substance which may render it injurious to health; or if it consists in whole or in part of any filthy, putrid, or decomposed substance; or it has been prepared, packed, or held under insanitary conditions whereby it may have become contaminated with filth or rendered injurious to health." With these stipulations, the presence of any microorganisms or chemical that may cause illness or that would indicate that the food may 
contain harmful agents makes the food adulterated and subject to seizure. The presence of filth, such as insects or rodent hairs or droppings, is evidence of an adulterated product. However, there are tolerances for these agents (see Chapter 13). Even if the food does not actually contain filth or potentially harmful agents, if conditions exist so that these substances may be present, the food can be considered adulterated. Although this act applies only to foods in interstate commerce, many states have copied the federal regulations.

The buildings, environment, and processing facilities, as well as raw materials, personnel, equipment (including cleaning and sanitizing), and refuse disposal facilities, are important to the overall plant operations.

The level of sanitation maintained in the plant has a direct bearing on the quality of the final product and should be a basic part of the quality-control program of the processor.

Quite often, a sanitation program is considered to be a cost that is passed on to the consumer, making the price of the food product less competitive. More realistically, unsanitary conditions result in increased costs, which increase the price of the food to the consumer. Additional costs, such as those caused by loss of food due to a short shelf life and spoilage of perishable products, medical bills of consumers ingesting pathogenic organisms or poisons, legal fees, and settlement of court causes due to illness or death of former consumers, are passed on to present consumers. Regulatory agents may seize a product that violates the regulations. As a result, the least that can happen to a food processor is to have inventory tied up. The seizure may result in destruction of the product, corporation or personal fines, prison terms, and the closing of the processing plant. Hence, although sanitation may be a cost, the lack of sanitation can create a greater cost. Sanitation is a necessity in order for a food processor to stay in business and has resulted in advantages to both the processor and the consumer.

Proper sanitation reduces or eliminates potential spoilage hazards and creates a longer shelf life of perishable products. This reduces losses due to spoilage, increases the efficiency of plant opeations, results in easier maintenance of equipment, develops better employee relationships, workmanship and safety, increases consumer acceptance and public relations, improves the quality and safety of foods for the consumer, and with better consumer acceptability, there is a potential increase in sales. This results in faster turnover and less spoilage of perishable foods. As a result of these benefits, the actual cost of the product may decrease.

The "may have" section of the U.S. Food, Drug, and Cosmetic Act of 1968 (Section 402 (a) (4)) describes adulterated food. To help interpret this description and to establish criteria to aid industry in complying with this section of the act, the FDA has published regulations called current 
good manufacturing practice (CGMP) for various foods. These regulations cover essentially all operations of a food-processing plant, including its outside appearance, equipment, processes, and personnel. The USDA regulates the processing of meat, poultry, eggs, and egg products.

Each food-processing operation has certain points at which failure to prevent contamination can be detected by laboratory tests with maximum assurance and efficiency. These are known as critical control points. Bauman (1974) defined hazard analysis as the identification of sensitive ingredients, critical process points, and relevant human factors, as they affect product safety. Together these form the concept called hazard analysis critical control points (HACCP).

Foods have been placed into five categories in terms of health hazards, which are based on three hazard characteristics (NAS 1969). These are described in Chapter 6 in regard to controlling Salmonella in foods. These hazard characteristics are used as the basis for the HACCP inspections.

According to Kauffman (1974), the HACCP inspection approach is used to determine the points in the process that are critical to the safety of the product, and these can then be used by the processor to identify critical points. HACCP inspections, guided by the CGMPs, will tell the FDA and industry what needs to be done to assure safe, high-quality food production and distribution.

The critical control points are determined for each type of food process and for each food-processing plant. The critical control points have been discussed for frozen foods (Peterson and Gunnerson 1974), canned foods (Ito 1974; Warne, Capaul, and Moffitt 1985), and a foodservice system (Cichy, Nicholas, and Zabik 1982).

With this concept of inspection, not only is visible evidence of filth (insects, rodents) or unclean equipment and facilities important, but also the microbial analysis for potential hazard or spoilage types is used at critical control points to determine the problems involved in the process. This concept increases the importance of the microbiologist.

Although the CGMP and HACCP concepts provide a basis for satisfactory operation for food processors, they do not state how to meet the requirements in all cases, or why some of the CGMPs are needed. There. fore, it seems worthwhile to discuss some of the these factors.

PLANT AND GROUNDS. The plant should be designed so that materials can be received, stored, processed, warehoused, and shipped in an efficient and satisfactory manner.

Some operations, such as washing dirt off vegetables or slaughtering animals, are not considered to be clean activities and must be separated 
from areas where processed food is exposed. The segregation of facilities should be such that no cross-contamination can occur between raw products and processed products.

AIR. Fresh air is needed in food-processing areas. Since air is a potential source of microorganisms, a system or systems are needed for microbial control. The sources of microorganisms and the means of dispersal throughout the plant must be considered in designing a method for control.

The ventilating system is the main place to control microorganisms in the air. Filters have been developed to remove microorganisms, as well as other materials from air. Viruses were effectively removed from air by filters with an efficiency rating of 93 percent or higher (Roelants, Boon, and Lhoest 1968). There are filters available with ratings of 99.9 percent and an ultra filter of 99.999 percent. The filter should be rated by the dioctyl-phthalate filter test using $0.3 \mu \mathrm{m}$ particles to challenge the filter. However, in some cases, organisms such as Bacillus spores (Robertson and Frieben 1984) or Pseudomonas cells (Leahy and Gabler 1984) have been used to test filter systems.

By pumping in more filtered air than is removed by the outlets, a positive air pressure is established in the room. With positive air pressure, when a door is opened for personnel or product to move in or out of the room, unfiltered air will not come in, since air is moving only out of the room. The clean, fresh air should enter the cleanest areas of the processing plant, move to the less clean areas, and leave the plant from the areas that are "dirty." This procedure reduces the potential airborne contamination of processed product from these less clean areas.

To eliminate turbulence factors, laminar airflow (unidirectional) has been developed. Laminar airflow devices are effective in reducing and controlling airborne contamination. Due to the relatively higher cost, they have not been readily adopted for use in the food industry. They should find usage in cabinets or special rooms where contamination of products must be tightly controlled, such as in aseptic packaging.

Besides mechanical filters, the air may be treated by chemical germicides, UV radiation, electronic air cleaners, thermal sterilization, centrifuging, or "scrubbing." When meticulous air cleaning is essential, electrostatic precipitation might be employed. The larger the particles, the easier it is to remove them. Thus, molds and yeasts can be removed by electrostatic precipitation more easily than bacteria or viruses. Due to the high cost of installation, this system has been used seldom, if at all, in the food-processing industry. Electrostatic precipitation is used to remove dust and other pollutants from effluent air. 
WATER. The water may be from a municipal supply, in which case it should be potable, that is, free from potential pathogens. However, municipal water is not tested for potential spoilage organisms, and reservoirs and pipelines at the plant can serve as a place for multiplication. Some pseudomonads grow in distilled water. Hence, it may be necessary to treat the water by chlorination at the processing plant.

The chemicals in the water influence the type of cleaning agents that are used in the processing plant. When water is an ingredient of the food, chemicals causing odors and flavors may affect the characteristics of the food product. In these cases, the water should be monitored and given the necessary treatments that are indicated by the analysis and by the food that is being processed. The treatment of water ranges from filtration, flocculation, softening, demineralization, reverse osmosis, distillation, to various combined processes to obtain pure water. A water softener is not a means of removing organisms and, in some cases, the resins in softeners may act as a source of inoculum of the soft water.

EQUIPMENT AND UTENSILS. The equipment should be designed so that food does not become lodged on or in it to form pockets of microbial growth for continual contamination of foods moving over or through it. The sanitary design of equipment results in easier cleaning and sanitizing, thereby saving labor and materials.

The equipment surfaces in contact with food must be nontoxic, nonabsorbent, nonporous, and noncorrosive. Although equipment is made of several types of material, stainless steel is preferred for surfaces that are in contact with food.

Stainless steel is not just one metal, but is a group of alloys of iron with chromium, nickel, carbon, molybdenum, titanium, silicon, phosphorus, manganese, and sulfur.

Although stainless steel is corrosion resistant, it is not corrosion proof. Stainless steel is protected from corrosion by its self-repairing surface film of chromium oxide. When this film is broken down by cleaning, it will reform when exposed to the air. If abrasive materials are used in cleaning, the metal surface will be scratched, which allows corrosion to occur. If harsh chemicals are used in cleaning, they can cause pitting of the metal. Scratches and pitting make it difficult to clean, sanitize, and maintain the equipment in a satisfactory manner. Scanning electron microscopy revealed that there were flaws such as scratches, cracks, and pits in samples of stainless steel prior to any stress or wear (Stone and Zottola 1985a).

Certain materials should not be used in equipment that contacts food. Due to its porous nature and difficulty in maintenance, wood should not be used. Copper and its alloys accelerate rancidity of fats, discolor food 
products, and contaminate foods with copper salts. Cadmium is toxic. Lead should not be used, except in small amounts when soldering is needed. Aluminum is attacked by acids and alkalis and it has a tendency to rub off and cause black marks. Iron can cause off-flavor in products, such as milk, and it is impossible to clean because of rusting and pitting. Zinc and antimony are not acceptable metals for surfaces in contact with food.

As an alternative to stainless steel, glass (usually borosilicate glass pipelines) or glass fiber-reinforced polyester resin are used in some food-processing plants. A unique substitute for metal is the use of liquid jets for cutting. This system is based on the principle of forcing a liquid (water, glycerine, vegetable oil, alcohol) through a tiny nozzle at extremely high pressure. These conditions accelerate the liquid to about $1,000 \mathrm{~m} / \mathrm{sec}$. This results in a more sanitary cutting method than using knives, and it is easier to maintain in a sanitary manner.

There are some areas or conditions in which flexibility is needed, and plastics or rubber products are used. Plastics may not be acceptable if they contain free phenol, formaldehyde, or any other substance that can transfer to or alter the food. Since additives used in the manufacture of plastics can be transferred to foods, the suitability of each type of plastic must be determined for each particular food.

Ease of assembly and disassembly is important if the equipment is to be cleaned by hand methods. When possible, equipment should be designed for clean-in-place (CIP) or automatic methods. These systems may cost more at the beginning but usually pay for themselves by requiring less labor and more effective cleaning and sanitizing.

The design and installation of equipment for proper drainage are important. This is needed in CIP systems, so that soil removed by cleaning solutions, as well as the cleaning solutions, sanitizing solutions, and rinse waters can be removed from the equipment.

Many years ago, 3-A Sanitary Standards for dairy equipment were developed (Atherton 1986). Since then, equipment standards have been written for other food products. These standards can be found in publications such as the Journal of Food Protection and Dairy and Food Sanitation.

Processing equipment does not have a normal microbial flora. It becomes contaminated with food residues that can support high levels of microorganisms. As the buildup of the microbial load progresses, it becomes a source for contaminating food that contacts it. Hence, it is necessary that the equipment be cleaned and sanitized at appropriate intervals to keep the microbial load at a reasonable level.

Cleaning. Equipment that is less than 100 percent clean is still dirty. It is difficult, if not impossible, to sanitize equipment that is not completely clean. Therefore, cleaning is a very important part of the operation. 
Before cleaning, the food must be removed from the line and protected from the possible contamination by the cleaning and sanitizing agents, as well as the water and soil removed from the equipment.

In some processing plants, all of the equipment is cleaned and sanitized manually. In other plants, some or all of the cleaning and sanitizing may be semiautomated or fully automated. In any of these systems, the human factor is the most important ingredient, since even with a fully mechanized system, it is necessary to set up the operation and supply the system with the cleaning and sanitizing agents.

The first part of any cleaning operation is to remove waste material and to rinse loose soil from the surfaces with clean water. For fatty materials, hot water may aid in this initial rinse, but cool water is desirable for protein soils (Anderson et al. 1985; Dunsmore et al. 1981; Koopal 1985; Middlemiss et al. 1985).

Even if most of the soil can be removed by hand and by water rinsing, the equipment is still not clean, since a residue remains that is difficult to remove. An input of energy is needed to remove this residual soil. The energy forms are thermal (hot water, steam), chemical (cleaning agents), and mechanical (high-pressure spray, manual scrubbing). Not only is soil attached to the equipment surfaces by physical forces, but microorganisms are also attached and are difficult to remove (Powell and Slater 1982; Stanley 1983; Stone and Zottola 1985b).

The cleaning process consists of bringing the cleaning solution into intimate contact with the soil on the equipment surface, removing the soil from the equipment, dispersing the soil into the cleaning solution, and preventing redisposition of the soil, as well as scale due to hard water, onto the cleaned surface. Various cleaning agents are available that perform these activities. Cleaning agents are designed to reduce the amount of work needed to remove the adhering soil.

Cleaning Agents. A cleaner may consist of a single compound or be a complex mixture of various chemicals.

Only approved cleaners and sanitizers should be used in food-processing plants. Various government agencies compile lists of compounds considered to be acceptable and safe for washing food-processing equipment, as well as the floors and walls of plants.

A cleaning agent should have the following characteristics:

1. Quickly and completely soluble

2. Noncorrosive to metal surfaces

3. Nontoxic

4. Easily rinsed

5. Economical 
6. Stable during storage

7. Not harsh on the hands if used for manual cleaning

8. Possess germidical action, if required.

The types of cleaners and their properties are listed in Table 10.1. Substances that lower the surface tension of a liquid, or the interfacial tension between two liquids, are known as surface-active agents, or surfactants. Chelating agents are chemicals that can form a soluble ringlike complex with a metallic cation. In this form, the metallic ions do not form insoluble films on the equipment, but are removed from the equipment by rinsing. The chief organic chelating agents, or sequestrants, are sodium salts of EDTA and related compounds, the hydroxy carboxylic com. pounds (citric, gluconic, tartaric, and hydroxyacetic acids) and the aminohydroxy compounds (such as tetraethanolamine). The important inorganic sequestrants are the sodium polyphosphates (sodium pyrophosphate, sodium tripolyphosphate, sodium hexametaphosphate). They have a softening effect on hard water. The chelating agents can increase the effectiveness of sanitizing agents.

Conventional cleaners are used and rinsed with hot water. For lowtemperature cleaning of poultry and meat-processing areas, proteolytic enzymes are added to surfactants. The surfactants possess a penetrating and emulsifying action on fats, while the enzymes soften and break up protein soils.

SANITIZING. If the cleaning procedure removed all of the organic material, the equipment would not need to be sanitized. The sterilization of all equipment would be ideal, but it would be neither practical nor economical. Thus, we are satisified if the equipment is sanitized.

In some cases steam, hot water, or hot air is used for sanitizing. In most processing plants, these agents are not practical, so chemical sanitizers are used. Sanitizing does not mean that all living bacterial cells are destroyed or removed. A sanitized surface does mean, however, that all pathogenic or disease-producing bacteria, as well as a large percentage of nonpathogenic ones, are destroyed.

Some sanitizing agents are added to detergents (detergent-sanitizers) so that the bacteria are killed during cleaning. This single operation of cleaning and sanitizing saves time and labor. When chlorinated cleaners are used, the chlorine not only kills bacteria, but also aids in the removal of soil and reduces redeposition.

The effectiveness of a sanitizer depends upon the concentration and the time of exposure. The $\mathrm{pH}$ modifies the sanitizing action by affecting both the bacteria and the chemical. An increase in temperature usually increases the rate of sanitizing. The effectiveness of the sanitizer depends 


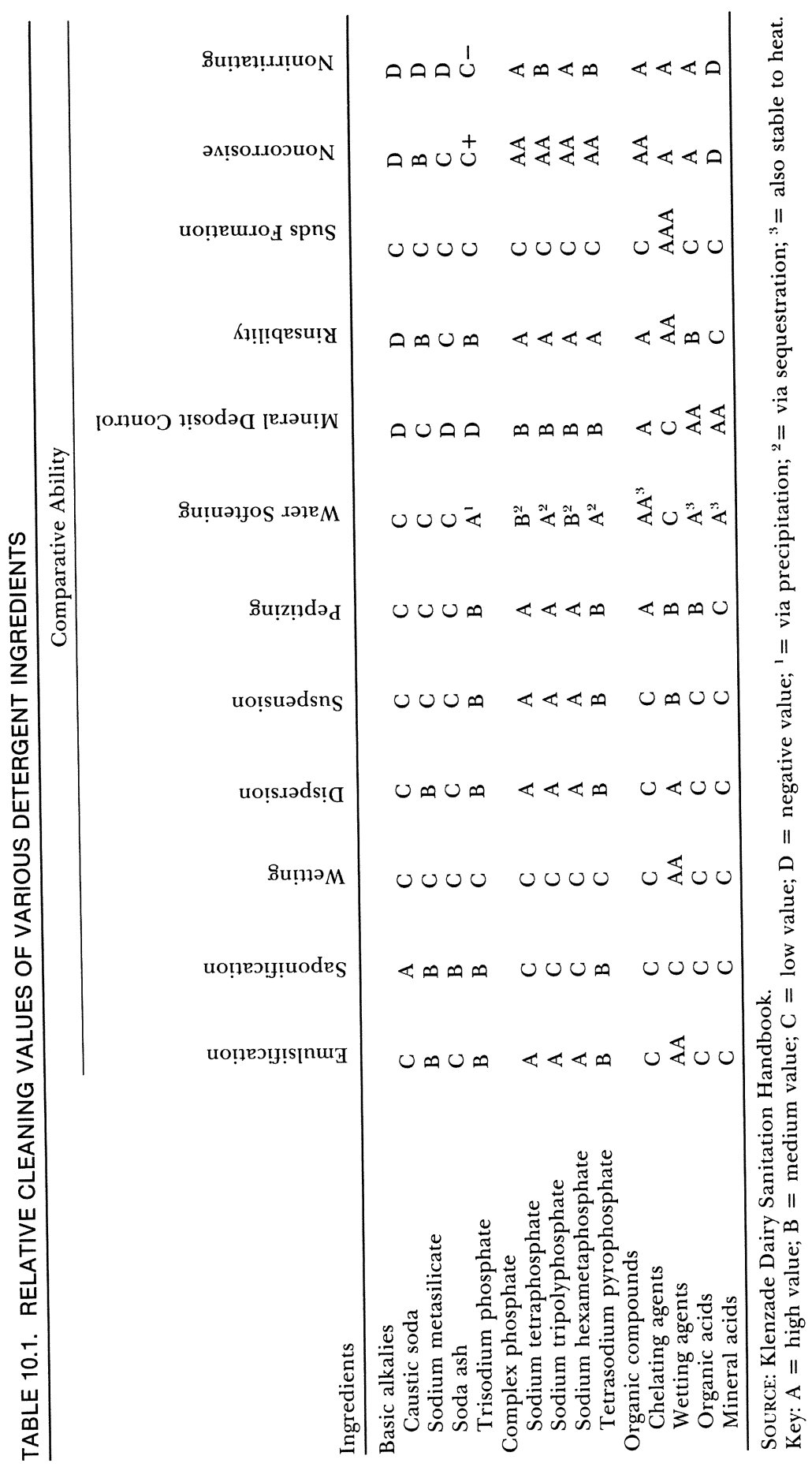


upon the types and numbers of microorganisms, as well as on their history. The use of a high concentration of a sanitizing agent as a substitute for thorough cleaning is inefficient and expensive, and, in some cases, may cause corrosion of the metal. Chemicals that leave bacteriostatic or bactericidal residues on surfaces may help with sanitation programs in food-processing plants.

Thousands of chemicals have germicidal powers, but only those compounds that are approved by a regulatory agent can be used as sanitizers. The four most popular types of sanitizers are the chlorine compounds, iodine or iodophors, quaternary ammonium compounds, and acid-anionic surfactants.

Chlorine. The most widely used sanitizers are the chlorine-containing compounds. Six factors determine the effectiveness of chlorine as a sanitizing agent. They are (1) type and concentration of chlorine compound used; (2) pH; (3) temperature; (4) contact period; (5) types of organisms; and (6) presence of organic material.

The types of chlorine compounds include the sodium and calcium hypochlorites, the salts of isocyanuric acid, the hydantoin derivatives and chlorinated trisodium phosphates, as well as gaseous chlorine. In powered chlorinated cleaners the source of chlorine is usually chlorinated trisodium phosphate, potassium dichlorocyanurate, dichlorodimethylhydantoin, or chloramine $\mathrm{T}$. The first two give the most active chlorine in the cleaning solution. Besides these compounds, mixtures of chlorine and bromine, as well as chlorine dioxide, have been used as sanitizing agents. The most widely used agents in the food-processing area are the hypochlorites.

The advantages and disadvantages of the use of hypochlorites as sanitizing agents are listed in Table 10.2. The hypochlorites are effective at relatively high dilutions and are active against a wide range of bacteria and bacterial spores, as well as molds, yeasts, bacteriophages, and some viruses. The hypochlorites are considered to be more effective against Gram-negative than against Gram-positive bacteria. Viruses are more resistant than bacteria to the action of chlorine.

In moderately strong concentrations, the hypochlorites can cause irritation of the skin and may cause an objectionable odor. In some cases, unacceptable flavors may develop in foods exposed to hypochlorites. There is a reduction of efficiency of hypochlorites by organic compounds and oxidants. Due to their high corrosion potential, they should not be used at high temperatures or be allowed to contact the surfaces of equipment for excessively long periods.

Chlorine compounds are used in various aspects of food processing. They are added to water used for washing and conveying raw food products, for cleaning and sanitizing food-handling equipment, and for cool- 
TABLE 10.2. ADVANTAGES AND DISADVANTAGES OF HYPOCHLORITES AS SANITIZERS

\begin{tabular}{|c|c|}
\hline Advantages & Disadvantages \\
\hline $\begin{array}{l}\text { Relatively inexpensive } \\
\text { Quick acting } \\
\text { Not affected by hard water salts } \\
\text { Harmless residue, does not form a film } \\
\text { Effective at high dilution } \\
\text { Active against a wide variety of microor- } \\
\text { ganisms, including spores and phage } \\
\text { Relatively nontoxic at use dilutions } \\
\text { Nonstaining } \\
\text { Colorless } \\
\text { Easy to prepare and apply } \\
\text { Concentration easily determined } \\
\text { Can be used for water treatment }\end{array}$ & $\begin{array}{l}\text { Unstable during storage } \\
\text { Inactivated by organic compounds } \\
\text { Corrosive if misused } \\
\text { Irritating to skin } \\
\text { Odor may be undesirable } \\
\text { Precipitate in iron waters } \\
\text { Effectiveness decreases with increasing pH } \\
\text { of solution } \\
\text { May remove carbon from rubber parts of } \\
\text { equipment }\end{array}$ \\
\hline
\end{tabular}

ing heat-sterilized cans of food. Citrus packers in Florida dip or rinse fresh fruit in $200 \mathrm{ppm}$ for 2 min prior to shipment to prevent the spread of citrus canker, which includes the presence of dark-brown and yellow lesions on the fruit.

In-plant chlorination is accomplished by injecting gaseous chlorine or liquid sodium hypochlorite into the water supply of a processing plant by an automatic proportioner. Sufficient chlorine is added to satisfy the demand of substances present in the water (the breakpoint), as shown in Figure 10.1, and to give a free available residual chlorine of from 2 to 20 $\mathrm{mg}$ per liter. The free available chlorine is in the form of hypochlorous acid ( $\mathrm{HOCl})$ and hypochlorous ions $\left(\mathrm{OCl}^{-}\right)$. The combined chlorine residual is that chlorine reacted with amino nitrogen (chloramines). The total available chlorine includes the combined and free chlorine.

In-plant chlorination provides a continuous bactericidal action of chlorine on food-preparation equipment during its operation. The use of chlorinated water sprays at selected points reduces or prevents accumulation of microbial slimes and off-odors in food-processing plants. The total microbial load of the finished product tends to be lower in food plants with in-plant chlorination. Chlorination cannot substitute for good sanitary practices and good plant operations.

Sodium hypochlorite reacts with water to form hypochlorous acid and sodium hydroxide.

$$
\mathrm{NaOCl}+\mathrm{H}_{2} \mathrm{O} \rightleftarrows \mathrm{HOCl}+\mathrm{NaOH}
$$

Thus, the solution is alkaline, and the hypochlorous acid ionizes to form hydrogen ions and hypochlorous ions: 


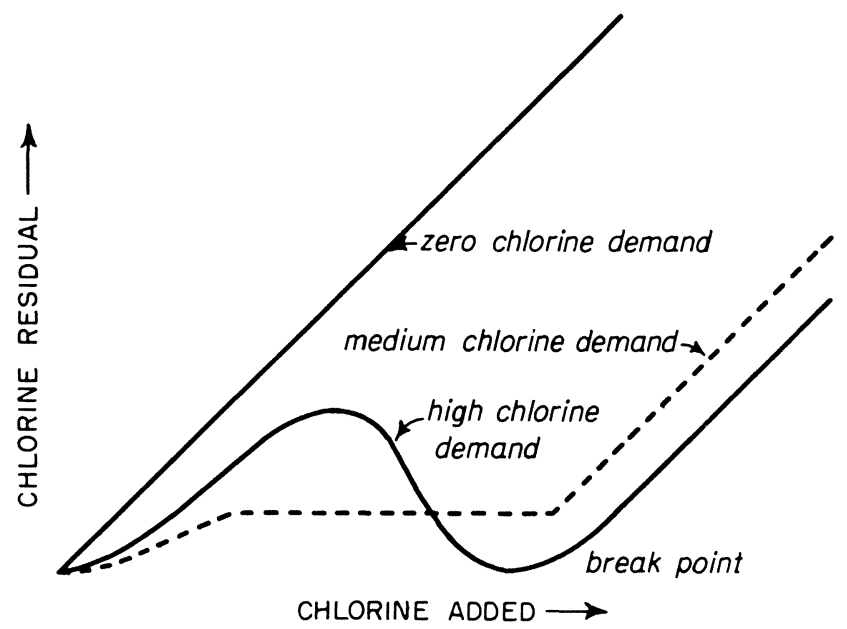

Figure 10.1. Chlorine demand characteristics of water. Courtesy of Heid and Joslyn (1967).

$$
\mathrm{HOCl} \rightleftarrows \mathrm{H}^{+}+\mathrm{OCl}^{-}
$$

The hypochlorous acid can dissociate to form hydrochloric acid and nascent oxygen:

$$
\mathrm{HOCl} \rightarrow \mathrm{H}^{+}+\mathrm{Cl}^{-}+\mathrm{O}
$$

The $\mathrm{HOCl}, \mathrm{OCl}^{-}$and $\mathrm{O}$ have germicidal properties. In an acid solution, the hypochlorous acid tends to remain as $\mathrm{HOCl}$, which is more bactericidal than the hypochlorous ion. Hence, the bactericidal efficiency of chlorine solutions is higher in acid than in alkaline solutions (Fig. 10.2) and is increased with temperature increases.

Apparently there is more than one mechanism by which chlorine compounds can affect living cells. Chlorine reacts with cell membrane proteins, forming $N$-chloro compounds. This impairs the transportation of nutrients (carbohydrates, amino acids) into the cells. Also, damage to the cell membrane can result in the leakage of cellular components from the cell. The HOCl can penetrate the cell and oxidize sulfhydryl groups on key enzymes, interfering with cellular metabolism and resulting in cellular death. It may react with DNA of living cells, and oxidize purine and pyrimidine moieties (Wlodkowski and Rosenkrantz 1975).

The effect of chlorine on spores of Bacillus and Clostridium was investigated by Wyatt and Waites (1975). They found that chlorine disrupts the spore coat by combining with and removing protein. This inactivated the 


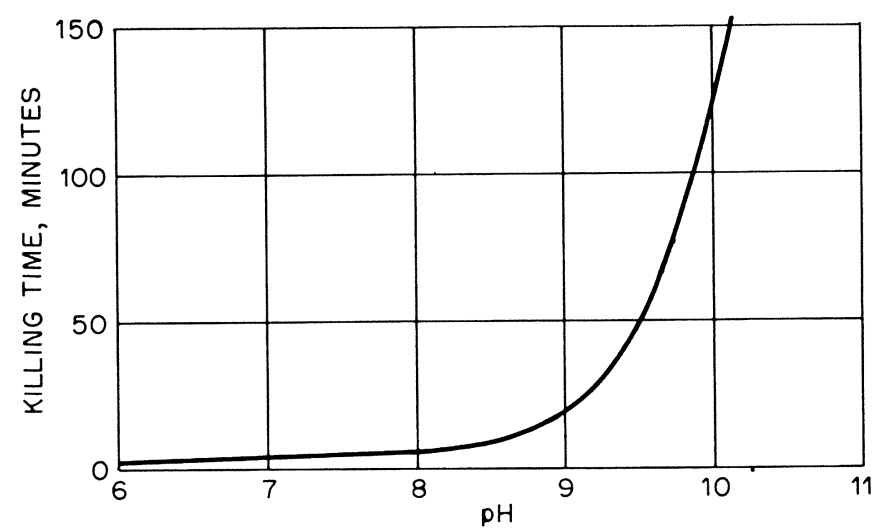

Figure 10.2. Effect of $\mathrm{pH}$ on germicidal efficiency of hypochlorite solution.

Courtesy of Heid and Joslyn (1967).

germination mechanism, but if spores were able to germinate, most were damaged to the extent that no outgrowth occurred. Degradation of $B$. subtilis spore cortex by chlorine appeared to correlate with loss of colony formation and may be the primary lethal effect (Gorman et al. 1984). The heat resistance of the spores was reduced by a chlorine treatment. Treatment of $B$. cereus spores with a solution of 0.25 percent $\mathrm{NaOCl}$ at $20^{\circ} \mathrm{C}$ for 19.5 min resulted in a 99 percent loss in viability (Kulikovsky, Pankratz, and Sadoff 1975). They found that the spores lost calcium ions, dipicolinic acid, ribonucleic acid, and deoxyribonucleic acid. The primary effect was the degradation of the outer spore coats, which led to a disruption of the normal permeability barriers. In general, Bacillus spores are more resistant than Clostridium spores to the action of chlorine (Foegeding 1983). However, Bacillus spores were more sensitive to chlorine dioxide than were Clostridium spores (Foegeding, Hemstapat, and Giesbrecht 1986). Spores are about ten times as resistant to chlorine as are vegetative cells.

Chlorine inactivation was due to degradation of RNA of polioviruses (O'Brien and Newman 1979). The rate of inactivation of viruses is affected by $\mathrm{pH}$, temperature, chlorine concentration, viral aggregation, and the type of virus (Engelbrecht et al. 1980; Harakeh and Butler 1984; Keswick et al. 1985; Vaughn, Chen, and Thomas 1986).

For sanitizing equipment, regulatory agencies recommend a chlorine concentration of 100 to $200 \mathrm{mg}$ per liter, with a holding time of $2 \mathrm{~min}$. A 200-mg-per-liter hypochlorite solution circulated for 2 to $5 \mathrm{~min}$ is usually satisfactory for sanitizing pipes cleaned in place. Enclosed vats or tanks can be sanitized by fogging with a chlorinated ( $200 \mathrm{mg}$ per liter) 
solution. With open vessels or vats, the sanitizer can be pressure-sprayed onto the surfaces.

The use of chlorine has received a great deal of bad publicity because of its reactions with organic compounds and the resultant mutagenic and carcinogenic potentials. Due to these aspects, it has been suggested that, in some cases, the use of chlorine may create a health hazard. The use of chlorine dioxide, however, does not seem to produce these toxic compounds (Wei, Cook, and Kirk 1985).

Iodine. Iodine is well recognized for its germicidal properties against a wide variety of microorganisms. However, its corrosiveness, toxicity, instability, low solubility in water, and other unacceptable characteristics have limited the usefulness of iodine in food plants.

An iodophor is a combination of iodine and a solubilizing agent, usually a surface-active agent (surfactant), which, when added to water, releases free iodine at a low rate. The surfactant can be nonionic, cationic, or anionic, but certain nonionic types are preferred. The advantages and disadvantages of using iodophors as sanitizers are listed in Table 10.3.

As with hypochlorites, the iodophors show greater bactericidal activity at an acidic pH. Hence, phosphoric acid buffers are added to the sanitizer to maintain the $\mathrm{pH}$ at 4.0 to 5.0 .

In the iodophor combination, the germicidal properties of iodine are maintained or enhanced, but the characteristic odor of iodine is elimi-

\section{TABLE 10.3. ADVANTAGES AND DISADVANTAGES OF IODOPHORS}

\section{AS SANITIZERS}

\begin{tabular}{|c|c|}
\hline Advantages & Disadvantages \\
\hline $\begin{array}{l}\text { Good stability } \\
\text { Long shelf life } \\
\text { Surface activity } \\
\text { Generally active against all microoorgan- } \\
\text { isms except bacterial spores and bacteri- } \\
\text { ophages } \\
\text { Destroy yeast cells at a greater rate than } \\
\text { do hypochlorites } \\
\text { Not affected by hard water salts } \\
\text { Relatively nontoxic } \\
\text { Not corrosive } \\
\text { Do not penetrate the skin } \\
\text { Good penetrating and spreading proper- } \\
\text { ties } \\
\text { Acid nature prevents mineral film forma- } \\
\quad \text { tion } \\
\text { Built-in color indicator } \\
\text { Concentration easily determined } \\
\text { Less sensitive than hypochlorites to or- } \\
\text { ganic matter } \\
\text { Easily dispensed and controlled }\end{array}$ & $\begin{array}{l}\text { Effectiveness decreases with increase in } \\
\mathrm{pH} \text {, such as carryover of alkaline deter- } \\
\text { gent solutions } \\
\text { Less effective than chlorine against bacte- } \\
\text { rial spores and bacteriophages } \\
\text { May cause off-flavors in dairy products } \\
\text { Should not be used at temperatures above } \\
49^{\circ} \mathrm{C} \\
\text { May cause discoloration } \\
\text { More expensive than chlorine } \\
\text { Causes staining of some material such as } \\
\text { plastic hoses }\end{array}$ \\
\hline
\end{tabular}


nated. At the recommended dilution, the iodophor solution has a rich amber color and, as it is used, the color fades. Hence, the iodophors have a built-in indicator of effectiveness.

The iodophors have good stability with a long shelf life. A high degree of surface activity gives them good penetrating and spreading power and aids in quick draining. Residues or films of minerals are prevented, since they are solubilized by the acid nature of the iodophors.

Iodophors cannot be used at temperatures above $49^{\circ} \mathrm{C}$ due to sublimation of the iodine, which results in loss of effectiveness.

Although the iodophors have good germicidal properties, they are less effective than hypochlorites against bacterial spores and bacteriophages.

There is less reaction of iodophors than hypochlorites with organic matter. However, the germicidal power is reduced by starch.

The widespread use of iodophors to sanitize equipment on dairy farms in Australia resulted in higher-than-normal levels of iodine in milk (Wheeler, Fleet, and Ashley 1982). This, in turn, caused thyroid problems in some consumers of dairy products.

Quaternary Ammonium Compounds. The quaternary ammonium salts (quats) have the general formula<smiles>[R1][N+]([R4])([R4])[R1]</smiles>

The $R$ stands for organic groups ranging from methyl $\left(\mathrm{CH}_{3}\right)$ to longchain aliphatic groups $\left(\mathrm{C}_{8} \mathrm{H}_{17}\right.$ to $\left.\mathrm{C}_{18} \mathrm{H}_{37}\right)$ and phenyl groups. For bactericidal properties, at least one $R$ is a plain or substituted long-chain aliphatic group. The $X$ is an anion, such as a halide $(\mathrm{Cl}, \mathrm{Br})$, sulfate, or acetate.

The quats may be bacteriostatic in low concentration and bactericidal in high concentration. Their lethal effect has been attributed to various activities, including reactions with cell membranes, denaturation of essential cell proteins, or enzyme inactivation. The effects on the cell membrane may be due to membrane lysis, membrane enzyme inactivation, or interference with the transport system. Quats may act on the cells by increasing the permeability of the cell membrane, allowing water to enter until the cell bursts.

The quaternary ammonium compounds have certain advantages and disadvantages when used as sanitizing agents. These are listed in Table 10.4 .

The quats are not as effective as the hypochlorites in destroying bacte- 
TABLE 10.4. ADVANTAGES AND DISADVANTAGES OF QUATERNARY AMMONIUM COMPOUNDS AS SANITIZERS

\begin{tabular}{ll}
\hline Advantages & Disadvantages \\
\hline Stable & $\begin{array}{c}\text { Incompatible with anionic agents in deter- } \\
\text { gents } \\
\text { Long shelf life }\end{array}$ \\
$\begin{array}{l}\text { Stable to temperature changes } \\
\text { Effective in alkaline conditions }\end{array}$ & Low activity in hard water \\
Noncorrosive & Less effective in activity against spores \\
Odorless & and bacteriophage, as well as coliforms \\
Less affected by organic matter & and psychrotrophs \\
Residual bacteriostatic effect & Need to rinse residual film from equip- \\
Nonirritating to the skin & ment \\
Easily dispensed and controlled & Problem with foam during mechanical ap- \\
Control off-odors & plication \\
Nontoxic & \\
Active against many microorganisms, espe- & \\
cially thermoduric types & \\
Good penetration qualities & \\
Combined with nonionics for detergent & \\
sanitizing agents & \\
\hline
\end{tabular}

rial spores of Gram-negative bacteria, including coliforms and psychrotrophs. They are definitely inferior in acting against bacteriophages. However, the addition of certain sequestering agents enhances the virucidal activity. In general, the quats are very effective against Gram-positive bacteria.

Generally, residues of quats are not allowed on equipment when food is being processed. Therefore, it is necessary to rinse the equipment, preferably with chlorinated water, prior to processing food.

Acid-Anionic Surfactants. These are combinations of an organic or inorganic acid (usually phosphoric) with a surfactant (usually an alkylaryl sulfonate). The low $\mathrm{pH}$ as well as the activity of the surfactant provide a bacteriostatic or bactericidal effect. The advantages and disadvantages of this class of sanitizers are listed in Table 10.5.

RAW MATERIALS. To control the raw material, it may be necessary for the processor to become the producer. For ingredients not directly controlled, specifications are needed, if for no other reason than to prevent the acceptance of rejects from another company. The specifications must be written so that they are flexible, but rigid enough so that they are useful. Some conditions for microbiological specifications of raw materials were described by Davies (1968) and Mossel (1969). The allowable number of the significant types of microorganisms, as well as the processing treatment that these ingredients are given, should be considered. The presence of microorganisms that may be a public health hazard should 
TABLE 10.5. ADVANTAGES AND DISADVANTAGES OF ACID-ANIONIC SURFACTANTS AS SANITIZERS

\begin{tabular}{lc}
\hline Advantages & Disadvantages \\
\hline Stable & Effective only at acid pH (optimum range \\
Long shelf life & $1.9-2.2$; above 3.0 , action decreases rap- \\
$\begin{array}{l}\text { Active against a wide spectrum of micro- } \\
\text { organisms including thermodurics, con- }\end{array}$ & $\begin{array}{c}\text { idly) } \\
\text { trols phage and most yeast strains. }\end{array}$ \\
$\begin{array}{l}\text { Residual antibacterial film } \\
\text { Noncorrosive and nonstaining to stainless } \\
\text { steel }\end{array}$ & $\begin{array}{c}\text { Foam problem in mech sporeformers, not ef- } \\
\text { in-place applications }\end{array}$ \\
$\begin{array}{l}\text { Relatively low toxicity } \\
\text { Effective in hard water or with organics }\end{array}$ & \\
Action enhanced at high temperatures & \\
\hline
\end{tabular}

be of concern to the processor, especially if the processing treatments do not destroy these potential pathogens. Spoilage organisms cannot be overlooked. The presence of a significant number of resistant bacterial spores in ingredients such as sugar, flour, or spices may cause spoilage of canned foods.

Before worrying about microbial analysis, the raw materials should be given a preliminary examination with normal human senses for evidence of filth or decomposition. The presence of rodent pellets or hairs, insect infestation, field rot, or decay of fruit and vegetables, a diseased condition of animals prior to slaughter, parasitic infestation of fish, or decomposition of the material are causes for rejection. Since the quality generally does not improve with processing, only clean and sound materials should be brought into the processing plant.

After the raw material is inspected and passed, it should be processed as soon as possible. When delays are unavoidable, facilities for storage should be maintained to protect the raw material from contamination and infestation as well as from deterioration. Some fresh raw materials can be modified by storage to obtain a more uniform product. An example is the storage of potatoes for making potato chips. At low temperatures, reducing sugars will accumulate and result in a dark potato chip. By conditioning these potatoes for a short time at high temperatures, the reducing sugars are returned to a low level.

Many foods have an outside peel, skin, or shell to protect the interior portion of the food from microorganisms. However, the organisms on the outside surface serve as a source of contamination when the protective covering is removed during processing. Hence, the raw material should be washed, when needed, to remove field dirt, other material, and many of the microorganisms from the outside surface. 
The washing of the raw food material should be done in an area separated from the rest of the processing facilities. The water should be free of microorganisms that may cause foodborne illness or spoilage.

OPERATIONS. It is important that the equipment is maintained, kept in good repair, and is properly cleaned and sanitized. When fruits and vegetables are cut or peeled, or an animal is killed and the hide removed, the natural defenses are broken down and the food is subject to contamination and the beginning of a chain of events that lead to quality loss and finally to destruction of the food.

Bacteria multiply rapidly. Therefore, the speed of handling becomes important. The operations should be timed so there is no backup of product, since long delays in processing can cause microbial problems. Bacteria develop more rapidly as the temperature rises; hence, the temperature should be kept as low as possible in keeping with processing requirements.

When organisms attain a high level in a food, even if they are inhibited or killed, their enzymes may remain active and cause changes in texture, flavor, and color.

Equipment such as trays or vats must not be used interchangeably for raw and cooked products unless this equipment is completely cleaned and sanitized before being used for cooked products.

Equipment is designed to reduce the handling of foods by workers. This equipment causes less contamination than the people handling it if it is properly cleaned and sanitized.

To reduce the temperature of poultry carcasses, continuous chillers are used. With proper sanitation during processing, washing of the carcaasses before chilling, maintaining low water temperatures, chlorination of the chill water with an acceptable input of fresh water and ice, with resultant overflow of excess water, microbial contamination of the carcasses is reduced.

PACKAGING. Food containers and packages are made from paper, plastic, glass, and metal, as well as combinations of these materials. The package should identify and advertise the contained product as well as present an attractive appearace to give it sales appeal. The package usually gives the product a standardized shape. The main function of packaging is to separate the food from the surrounding environment so that the food is protected from recontamination by microorganisms and pests and from physical and chemical damage from atmospheric oxygen, light, storage odors, and moisture.

Packaging materials must meet certain standards. The package should 
be easily filled and emptied. It must be strong and durable, since damage to the package will result in contamination. The material used for packaging must not contaminate the food with foreign odors, flavors, or toxic substances. Further, the food must not corrode or weaken the package. The package must be able to withstand the processing treatment of the food (heating, freezing, cold storage), and the package must be obtainable at a reasonable cost.

If not properly handled and protected, the package may be a source of microorganisms. The food may acquire chemicals from the packaging materials, such as plastics or waxes, either alone or coated onto paper. Makinde, Gilbert, and Lachance (1976) listed chemicals such as monomers (ethylene, vinyl, propylene, styrene) and catalysts used in preparing plastics or various stabilizers, pigments, and antistatic, antifogging, bactericidal, and antifungal agents incorporated into plastics. Polycyclic aromatic hydrocarbons or carcinogens such as 3,4-benzopyrene may be associated with waxes. Polyvinyl chloride plastics are made from vinyl chloride, a human carcinogen.

With proper packaging, the greatest number of people can be supplied with a clean, wholesome supply of food. Extremes of food packaging are now available. The poisoning of packaged drug products with cyanide and the threatened contamination of foods have been responsible for an increase in tamper-evident packaging. These types of packages include film overwraps, blister-strip packs, bubble packs, shrink seals, sealed tubes, breakable caps, bottle seals, pouches, sealed cartons, aerosol sprays, and tape seals. This extra effort increases the cost of the product and in some cases makes it difficult for the consumer to open the package for use.

At the other extreme is no packaging. There is a growing trend for retail stores to sell bulk foods that are in a box, barrel, or case, or simply sitting on a shelf. The consumer selects the type and amount of foods and puts them into a container such as a plastic bag for purchase. It is questionable whether these foods are handled in a sanitary manner. Although these bulk foods are often presumed to be cheaper because of reduced labor and packaging costs, they may not actually be priced any lower per unit than packaged foods. At the same time, they offer a potential target for contamination by toxic substances. However, as long as bulk foods are purchased, the retailer will continue to allot more space for their sale, until a government agency decides that regulations are needed.

Different packaging materials vary in their physical and chemical properties. The permeability to moisture, oxygen, gases, light, and even microorganisms varies with different materials. With the various properties of packaging materials, the characteristics of a package can be engi- 
neered to fit almost any food product or processing and storage requirement.

PERSONNEL. People are an important cause of microbial contamination of foods. The CGMPs stress (1) disease control; (2) cleanliness; (3) education and training; and (4) supervision. The concern of the plant personnel for sanitation and personal hygiene must begin with plant management. Management must set a good example, furnishing the proper environment and establishing within the personnel a desire to comply with the requirements necessary to maintain sanitation and personal hygiene.

All personnel should be involved in keeping the processing plant neat and orderly. However, of special concern are those people who handle ingredients, foods, or food-contact surfaces. In the handling of creamfilled pastries, cooked meat and poultry products, milk products, and salads, the hygiene of workers is a critical control point (Bryan 1974).

Disease Control. Even with the development of equipment for various purposes, there is still direct handling or close contact of food by humans. Although equipment is a major source of microorganisms, these are usually spoilage types normally associated with foods. Humans are a potential source of pathogens. In this respect, humans are more important than equipment as a source of food contaminants.

Anyone who is sick, has a communicable disease, is a carrier of such a disease, or has boils, sores, or infected wounds must not be allowed to work in any area of a food plant where there is a possibility of contaminating the food or a food-contact surface.

According to California health authorities, education in food handling and personal hygiene, along with inspection of food establishments for sanitation, will prevent more foodborne disease than any program involving the routine screening of food handlers for communicable diseases. In general, the value of routine medical examinations of food handlers is questioned for the following reasons: (1) It has not been established that most outbreaks of foodborne illness are caused by food handlers; (2) medical examinations and laboratory tests are very expensive; and (3) because of the rapid turnover of food handlers, it is difficult to assure that all employees are examined.

Cleanliness. Employees should maintain a clean appearance. The CGMPs suggest the wearing of clean outer garments. Even though the employee may dress in clean clothing at home, it is not sterile. Furthermore, by the time of arrival at the plant, the clothing has been subjected to various sources of contamination, which can include both food-spoilage and disease-producing microorganisms. Hence, in some cases, it is required 
that employees wear special protective outer clothing that is not worn outside the processing plant. In the general guidelines for handling ready-to-eat products, employees who work on raw and ready-to-eat products must change any garment that has contacted a raw product. Due to human shedding of microorganisms, special clean-room clothing may be needed in selected areas. This clothing is essentially that worn in operating rooms, including coveralls or smocks with hand, foot, and head coverings. In many food plants, the employees wear company-furnished uniforms. Uniforms of different colors should be provided for different departments. In this way, there will be less chance for cross-contamination of food by personnel.

The hands are used for many things. Therefore, it is essential that before working with food, the hands are washed and, if necessary, sanitized. Simply rinsing the hands is not sufficient. Washing with soap and water does not remove all of the microorganisms; however, a thorough washing with soap and water will remove most of the transient organisms. Antimicrobial soaps will aid in removal of the resident flora. Sanitizing solutions for hand dips may contain chlorine, iodine, or any other approved bactericidal agent.

Not only are hand washing and sanitizing needed before beginning work, but also after each break, after leaving and returning to work, or when the hands may be contaminated from handling contaminated equipment or picking up debris from the floor.

The hand-washing facilities should be provided with foot-operated controls to obtain warm water. Tap handles have been found to be highly contaminated. It does little good to wash one's hands and then promptly contaminate them with enteric-type organisms from the tap handles.

Probably not surprising, McBride (1984) found that bar soap had significantly higher levels of organisms than did liquid soaps. Stiles and Sheena (1985) found that, of the products tested, only 4 percent chlorhexidine gluconate liquid detergent and iodophor containing 0.75 percent available iodine were significantly better than nongermicidal soap for reduction of transient bacteria. They also reported that a barrier cream on the hands reduced the shedding of organisms from the fingertips (Sheena and Stiles 1983).

In some cases, gloves are worn to control potential contamination. These should be disposable rubber gloves and should be maintained in a sound, clean, and sanitary condition.

Hair on the head, face, and body is a source of microorganisms, as well as loose hair that contaminates food. Hence, hair coverings, such as hair nets, beard nets, headbands, caps, or other effective hair restraints must be worn by employees.

Personnel should not have extraneous materials in the food-process- 
ing area. Smoking, chewing of gum or tobacco, spitting, eating, or drinking cannot be tolerated in areas that will affect the food. Also, the food must be protected from contaminants such as perspiration, cosmetics, and medicants.

With the regulations of various government agencies relative to such things as health and safety, no one except authorized plant employees or government inspectors should be allowed in the food-handling or processing areas.

People tend to have bad habits, forget what they are supposed to be doing, and get careless. People forget to wash their hands, or merely rinse them. Food is left at room temperature rather than being put into the refrigerator or freezer. Some people believe that there is nothing wrong with salvaging unfit food. It is relatively easy to observe examples of poor sanitation as well as questionable practices when eating in a restaurant or other foodservice unit.

In a processing plant, the cleanup crew must do a complete and thorough job of cleaning and sanitizing the plant and equipment. If they are not careful, they can contaminate the equipment more than they clean it. The food-processing crew must follow rules for acceptable operations.

Government inspectors should be clean and set an example for the plant personnel. It is illogical for an unkempt person to try to explain sanitation and personal hygiene to other people.

Training. Many food-processing jobs are seasonal and often offer relatively low salaries. Hence, the food industry tends to obtain young people, part-time workers, and various others who cannot find work elsewhere. Some of them are poorly trained people in the lower socioeconomic group. With this combination of jobs and types of people, the turnover rate is rather high and sanitary training is difficult.

The employees must be properly trained and retrained in the correct use of equipment, sanitation, and personal hygiene. They must be informed of the perishable character of the food product, sources of contamination, and their role in the production of a top-quality product.

Since a majority of outbreaks of foodborne illness are due to contamination or mishandling of food at foodservice establishments and in the home, it seems logical that the general population needs training in the care and handling of food products and in personal hygiene. A course concerning these aspects given in high school might be beneficial.

Supervision. The supervision of the plant sanitation and the sanitary training of personnel should be under the direction of a well-trained sanitarian.

The sanitarian and other plant supervisors must be able to recognize unsatisfactory employee habits or health problems. If employees cannot 
or will not follow the necessary rules, the supervisor must remove them from critical areas, since the supervisor is ultimately responsible for compliance with the regulations that are applicable to the product being processed.

\section{Microbial Evaluation}

A visual inspection of raw material, equipment, packages, and finished product can detect gross filth, but microbial analyses are needed to determine microbial contamination.

Samples for analysis should be obtained from the equipment surfaces, hands, raw material, the material during processing (on-line samples), finished processed product, and other things such as air, water, or packaging materials that might be involved in product contamination. Routine tests will show day-to-day variation and help reveal weaknesses in raw materials, ingredients, equipment sanitation, or personal hygiene.

Not only the total number of organisms, but also pathogenic types, such as Salmonella or Staphylococcus or indicators such as coliforms, Escherichia coli or enterococci, should be determined. In some processing plants the sporeforming bacteria (Bacillus, Clostridium, and Desulfotomaculum), yeasts, molds, psychrophiles (Pseudomonas), or other spoilage types might be evaluated. In the citrus industry, a colorimetric test for the presence of diacetyl and acetylmethylcarbinol is effective in quality control. These are metabolic products of the degradation of citric acid by species of Lactobacillus and Leuconostoc.

The total aerobic plate count of samples obtained from various stages of production may be used as a general index of plant sanitation. However, processing treatments such as heating will decrease the count, and the addition of certain ingredients may increase the number of microorganisms. If sharp increases in numbers occur in a particular area, this is evidence that something may be amiss and needs investigation and corrective action.

A significant increase in the day-to-day microbial level of equipment surfaces indicates faulty cleaning or sanitation. Close observation of the cleaning and sanitizing may reveal the problem so it can be resolved.

Microbial surveys of various foods reveal that products handled with good sanitary conditions usually have significantly lower counts than products produced by plants operating with poor sanitary conditions. There are times when poor sanitary practices are not revealed by microbial numbers of the final product, but with sufficient sampling over several sampling periods and analysis of on-line samples, a correlation can be obtained between plant sanitation and bacterial loads. When analyzed, the coliforms, E. coli, and coagulase-positive staphylococci counts 
generally reveal the sanitation of the plant and personal hygiene of the workers.

\section{Foodservice Establishments}

Of the reported outbreaks of foodborne disease in which the place of mishandling is known, most are due to foodservice establishments. If health authorities are truly interested in reducing the number of foodborne outbreaks, then foodservice establishments need more regulation and observation than has been evident. It is unfortunate that people must be forced to do an acceptable job of producing food. Too many owners of foodservice businesses have no background in sanitation and the proper handling of foods.

The same general requirement for housekeeping, equipment, cleaning, sanitizing, and personnel problems and regulations that apply to food-processing plants also are required for foodservice establishments.

In many food-processing plants, one or only a few foods are handled and processed, whereas in a restaurant all types of foods in various stages of processing are handled and utilized. Some raw foods are served with only a little preparation, such as in salads. Other foods, such as meats, are cooked. The common organisms (salmonellae and staphylococci) that cause foodborne illness are destroyed by cooking meat to an internal temperature of $74^{\circ} \mathrm{C}$ (Bryan and McKinley 1974). Hamburgers or other meats may not receive sufficient heat treatment during the cooking process to destroy pathogens. Cooked meats for sandwich use may be left at room temperature rather than being refrigerated. The same knives or other equipment used to handle raw meat may be used for cooked meat. Hence, there may be cross-contamination between raw and cooked products.

Foods that are prepared just prior to serving normally do not cause health problems. It is food that is prepared a day or two before serving and then not properly refrigerated, or food that, after preparation, is held for serving during a two- or three-hour lunch or dinner period that can cause problems of foodborne illness.

To prevent growth of microorganisms, warming tables should keep hot foods at or above $60^{\circ} \mathrm{C}$, and cold tables should keep cold foods at or below $7^{\circ} \mathrm{C}$. If foods are to be held for any period over two or three hours, they should be refrigerated.

Various accessories (salt, pepper, catsup, sugar, steak sauce, syrup) may be found on the table or served to several customers at different tables. The customers can be a source of microbial contamination, including potential pathogens, of these supplies.

Certainly things have improved since the days when only a superficial 
rinse was given to many utensils and glasses. However, further improvements are needed in the foodservice industry to eliminate contamination and foodborne illness.

Due to the rapid turnover of workers in the foodservice industry, for a national training program to work, it seemed advisable to train managers (Baker 1982), who could then train their personnel. There are fewer managers than workers, and managers tend to have less rapid turnover than the workers. A few health departments have made manager training mandatory (Wright and Feun 1986). However, the reports on voluntary manager training programs has indicated little, if any, benefit of manager training (Cook and Casey 1979; Wright and Feun 1986). Perhaps foodservice people are more interested in profit than in food service, or perhaps the training program needs to be revised so that it is more realistic.

The HACCP concept for food processing also can be used in foodservice operations (Bryan 1981). The examination of raw materials, processes, practices, personnel, products, equipment, and premises is used to determine things such as potentially hazardous foods, pathogenic foodborne organisms, and unacceptable employer practices, time-temperature combinations, procedures, and environmental conditions. Various foodservice operations have been studied with this concept in mind, including Mexican and Chinese foods, caterers and hospitals (Bryan and Bartleson 1985; Bryan and Lyon 1984; Bryan, Bartleson, and Christopher 1981; Bryan, Harvey, and Misup 1981; Bryan et al. 1982a, 1982b, 1982c; Snyder 1986).

Salad bars, smorgasbords, buffets, and Sunday brunches are the bulk food sections of the foodservice industry. Problems of salad bars, such as over-reuse of food, people's coughing and sneezing on the food, or sticking their fingers into the food for sampling were described by Dahl (1986). Fortunately, most vegetables and fruits found in salad bars are not involved in foodborne illnesses (Chapter 6). However, that is not true for many of the other self-serve foods. Surprisingly, the number of outbreaks of foodborne illness involving these foods found in self-serve systems has been relatively small (see Chapter 6). However, lesser known foodborne illnesses may be associated with consumption of these foods.

\section{Retail Stores}

The modern food supermarket resembles a group of food-processing operations as well as a foodservice unit mixed in with normal retail functions. Some stores have a meatcutting and -packaging area, a producepacking area, a candy-making area, a bakery, a delicatessen, an orange juice squeezer, and a lunchroom with a salad bar. 
With all of these activities going on, there are many chances for mishandling of food, with subsequent problems of foodborne illness. As discussed previously, the bulk food section is subject to contamination not only by store personnel, but also by the general public. Many other foods are not packaged in tamper-evident systems.

Wyatt (1979) pointed out the importance of sanitation in retail stores. However, the sanitary condition of the meatcutting area was not as im. portant as the original bacterial load on the carcass and temperature of holding in affecting the microbial contamination and shelf life of steaks or ground meat (Greer and Jeremiah 1980; Greer, Jeremiah, and Weiss 1983; Wyatt and Guy 1980). Obviously, if the original count is 100,000 per gram, the addition of another 10,000 bacteria will not have as great an effect as the multiplication of the original bacteria. However, sanitation should be practiced to aid in the control of pathogenic organisms.

To provide industry and governments (state and local) with a uniform system for the operation and regulation of retail food stores, the Association of Food and Drug Officials (AFDO) initiated and jointly developed with the FDA a sanitation ordinance (FDA 1982). It includes such things as general provisions, food (supplies, storage, preparation, display), personnel (health, cleanliness, clothing), equipment and utensils, cleaning and sanitizing, sanitary facilities and controls (water, sewage, plumbing), physical facilities, and compliance procedures.

\section{Sanitation at Home}

The practice of sanitation and personal hygiene in the home will go far toward preventing problems in other food-handling establishments. Many people seem to be unaware of their responsibility for proper home storage, hygienic food preparation, and sanitary practices in the kitchen. Efforts to improve food protection in the home must overcome family customs and personal habits.

For a foodborne illness to occur, a potentially pathogenic organism must be in an acceptable food environment for growth or production of toxin. A sufficient amount of this contaminated food must be eaten by a susceptible person for illness to occur. Thus, not all unsanitary acts will result in illness. The person who prepares the food becomes complacent and careless. Besides carelessness, other factors that may be involved in foodborne outbreaks are apathy, ignorance, and poor judgment.

Food protection in the home encompasses essentially the same systems as in the food-processing plant. It begins with the selection of food and continues with transportation, storage, preparation, serving, and handling of leftovers and wastes.

At the store, we can make a judgment about certain foods by their 
appearance. Damaged or opened packages should not be selected. If produce has a shriveled appearance, discoloration, evidence of mold, or other microbial growth, it should be avoided. In the frozen food counter, do not select packages that are piled above the freezer. Canned foods that show bulging or the leaking of contents should be pointed out to the manager. Although, in general, the food in dented cans may be satisfactory, this type of can does show evidence of rough handling. This could affect the can seams and result in spoilage or a health hazard.

Perishable food should be protected while being transported home. Allowing food to remain in a hot trunk of a car parked in a sunny parking lot for several hours will cause problems. Many people own cooling chests that give some protection to perishable foods during the period of transportation.

The home should have adequate space for dry storage as well as refrigerated storage. These areas should be kept neat and clean. The foods that are brought home must be promptly stored in the proper area, especially those that require refrigeration or freezing.

The food preparer should practice good personal hygiene. Thoroughly washing the hands is essential, and rewashing is needed when food-preparation activities are interrupted for any reason. It is expected that animals should be kept out of processing plants, but some people allow their house pets to run around the kitchen and think little about this. Rodent and insect control are as important at home as in the processing plant.

The kitchen should be kept clean. This includes the floors, walls, cupboard, stove, refrigerator, and other accessories. Pots and pans should be cleaned thoroughly. Have you ever seen anyone sanitize the utensils at home? This failure may account for some of the problems that occur in the home. Although wiping cloths in processing plants and foodservice establishments is considered to be unsatisfactory, it is unusual to find a home in which dish towels are not used to wipe at least some of the utensils or dishes.

Fresh meats, poultry, and fish should be cooked sufficiently to destroy pathogenic types of microorganisms. Eating raw animal products is not recommended. Cross-contamination between raw meats and prepared foods should be avoided.

With most meals, more food is prepared than is eaten. Hence, there are leftovers. If these are to be used again, they should be placed promptly into the correct storage conditions, and perishable foods should be refrigerated. It is not considered acceptable to prepare food ahead of time and allow it to remain at room temperature before serving. Sooner or later, this practice will result in illness.

Various sites in several homes were surveyed for microorganisms 
(Finch, Prince, and Hawksworth 1978; Scott, Bloomfield, and Barlow 1982). Surprisingly, except for washcloths, tea cloths, and sink and basin drains, most sites in the home had relatively low levels of contamination.

\section{CONTROL OF MICROORGANISMS BY REMOVAL}

One means of controlling microbial levels in food is the removal of microorganisms. The systems used commercially for this procedure include washing, centrifugation, and filtration.

\section{Washing}

Washing of fruits and many vegetables is used in the preparation of these foods for canning, freezing, or fresh consumption. Washing removes soil, microorganisms, and some residual pesticides (Munsch, Simard, and Girard 1982; Wright et al. 1979).

During processing, broiler carcasses go through a spray washer. This washing process removes many of the microorganisms from the carcass surface (Mulder and Bolder 1981; Notermans, Terbijhe, and Van Schothorst 1980).

Significant reductions in bacterial numbers on beef and lamb carcasses by using high-pressure water sprays have been reported. However, spray washing was considered to be impractical (Sheridan 1982), and there was no increase in storage life of the sprayed carcasses (Kelly, Lynch, and McLoughlin 1982). Kriaa, Arthaud, and Fournaud (1985) found that the microbial contamination of carcasses was not greatly affected by spray washing. One problem seems to be that bacteria become attached to meat surfaces and are then difficult to remove. The addition of acid (acetic or lactic) or sodium hypochlorite to the spray water yielded some increased benefits (Anderson et al. 1979; Skelley et al. 1985; Smulders and Woolthuis 1985; Woolthuis and Smulders 1985).

The addition of $\mathrm{KCl}(0.1 \mathrm{~m})$ to a water rinse resulted in a greater removal of microorganisms from meat surfaces (Appl and Marshall 1984). Pedraja (1973) recommended that fish or seafoods be passed under a spray of chlorinated $(10 \mathrm{mg} / \mathrm{L})$ water before and after processing to control bacteria.

Washing may not be beneficial in all cases. Fellers and Pflug (1967) reported that washing of pickling cucumbers "reduced the storage life to half that of unwashed fruit." The polishing of fruit with saran brushes can cause invisible injuries to the peel. This can result in increased decay during storage. 
If the washing of shell eggs is done improperly, there is increased spoilage during storage.

\section{Centrifugation}

This operation involves the separation of a solid from a liquid or a liquid from a liquid by means of centrifugal force. This process has been used in the preparation of sugar, clarification of fruit juice, and the separation of cream from milk.

By increasing the centrifugal force of the milk separator, it is possible to separate bacteria from the milk. In this centrifuge, the bacterial cells, as well as other sediment, are thrown to the vertical wall of the bowl. The outer edge of the bowl has two small holes $(0.3 \mathrm{~mm})$ through which about 1.5 percent of the milk containing from 90 to 97 percent of the bacteria is removed. By using two centrifuges in series, 99 percent or more of the bacteria in the original milk is removed.

Although originally described for milk, other applications have been developed, including the separation of microorganisms from substrate in the production of single-cell protein, the purification of molasses for use in the production of baker's yeast (Saccharomyces cerevisiae), and the separation of distiller's yeast from the substrate prior to distillation of the alcohol.

When bacteria are removed by centrifugation, there is no damage to the flavor or other quality factors such as occurs with heat. Also, the cells are removed, not just destroyed.

Spores are more dense than bacterial cells and are readily removed from liquid foods. The removal of over 99 percent of the heat-resistant spores and vegetative cells makes it easier to destroy the remaining spores by heat treatment.

There may be problems with some applications. Centrifugation also may remove some protein, calcium, and phosphorus from milk. To aid in separation, some foods may need to be heated. To centrifuge viscous molasses, it is diluted and heated.

The use of centrifugation is limited to liquid foods and then only when the density of the bacteria is greater than that of the food components. Since not all of the microorganisms are removed, these liquid foods cannot be considered sterile. However, by reducing the microbial load, it is easier to achieve sterilization by heat treating the food.

\section{Filtration}

Filtration is the separation of solids from a liquid or gas by subjecting the mixture to a porous material, the filter. The size of the filter pores determines the particles that pass through and those that are retained. 
Bacterial membrane filters (MF) have pores of $0.45 \mu \mathrm{m}$. However, if all but the smallest viruses are to be retained, a pore size of 0.1 to $0.2 \mu \mathrm{m}$ is needed. Although one manufacturer indicated that the pore size varied from 0.43 to $0.47 \mu \mathrm{m}$, according to Olson (1983) the range for pore diameter of this size MF is 0.20 to $1.0 \mu \mathrm{m}$. This variation is perhaps why a 0.20 $\mu \mathrm{m}$ size is recommended for sterilization.

There are some advantages in using membrane filters. The inert behavior, high initial flow rate, particle retention due to the "sieve" effect, no shedding of fibers, negligible loss of solution, and no effect on the concentration, $\mathrm{pH}$, color, or flavor of the filtrate are good features of a membrane filter (Grubert 1974).

Before the membrane or other filter is used to remove bacteria from substances, it must be sterilized. This usually is accomplished by means of steam heat, ethylene oxide, or gamma radiation. After filtration, all pipes, filling apparatus, and packages must be sterile or the product will be recontaminated.

Filtration is used in the sterilization of media or media components that are adversely affected by heat treatment. It is used in the microbial analysis of liquids, such as potable water with low microbial counts (membrane filtration method).

Millipore (1970) listed several uses for membrane filters. These include (1) the filtration of beer or wine for cold pasteurization or for analysis of yeasts and bacteria; (2) filtering air to determine microbial contamination or to remove microorganisms and other particles from air used in contact with food products, in fermentation vats, and in packaging food products; (3) in the analysis of additives, pipelines, packaging equipment, and foods, such as soft drinks, syrups, and liquid sugar for microbial contamination; (4) remove yeasts and bacteria for the biological sterilization of champagne; and (5) remove microorganisms or particulate material from water, such as that used in blending of alcoholic beverages, to achieve clarity.

Cold pasteurization or sterilization by filtration can be used for clear fruit juices, vinegar, soft drinks, syrups, and vegetable oils. Since filtration to remove bacteria does not destroy or remove enzymes, if these cause undesirable reactions in foods, heating must be used to inactivate them. With ultrafiltration, enzymes can be removed. Systems such as reverse osmosis or ultrafiltration can be used to concentrate foods prior to drying.

Filtration has some advantages, as well as disadvantages, as a means to control microorganisms in foods. Among the advantages are that less energy is needed to filter than to heat liquid foods. Not only are the microorganisms removed, but particulate matter is also removed, and clarity is thus improved. Problems include the prefiltering or clogging of the filters, the residual enzymes, the necessity for sterilizing the filter system 
prior to use, and the necessity for observing aseptic handling and packaging.

\section{REFERENCES}

Anderson, M. E.; Huff, H. E.; and Marshall, R. T. $\quad$ 1985. Removal of animal fat from food grade belting as affected by pressure and temperature of sprayed water. J. Food Prot. 48: 246-248.

Anderson, M. E.; Marshall, R. T.; Stringer, W. C.; and Naumann, H. D. $\quad$ 1979. Microbial growth on plate beef during extended storage after washing and sanitizing. J. Food Prot. 42: 389-392.

Appl, C. P., and Marshall, R. T. 1984. Detachment of Pseudomonas fluorescens P26 from beef rinsed in salt and acid solutions. J. Food Prot. 47: 537-541.

Atherton, H. V. 1986. The 3-A story. Dairy Food Sanit. 6(3): 96-98.

Baker, K. J. 1982. The food service manager training and certification program. Dairy Food Sanit. 2(6): 228-230.

Bauman, H. E. 1974. The HACCP concept and microbiological hazard categories. Food Technol. 28(9): 30, 32, 34, 74.

Bryan, F. L. 1974. Microbiological food hazards today-Based on epidemiological information. Food Technol. 28(9): 52, 54, 58-60, 62, 64, 66.

Bryan, F. L. 1981. Hazard analysis of food service operations. Food Technol. 35(2): 7887.

Bryan, F. L., and Bartleson, C. A. 1985. Mexican-style foodservice operations: Hazard analyses, critical control points and monitoring. J. Food Prot. 48: 509-524.

Bryan, F. L.; Bartleson, C. A.; and Christopherson, N. 1981. Hazard analysis, in reference to Bacillus cereus, of boiled and fried rice in Cantonese-style restaurants. J. Food Prot. 44: 500-512.

Bryan, F. L.; Bartleson, C. A.; Sugi, M.; Miyashiro, L.; and Tsutsumi, S. 1982a. Hazard analyses of fried, boiled and steamed Cantonese-style foods. J. Food Prot. 45: 410-421.

Bryan, F. L.; Bartleson, C. A.; Sugi, M.; Sakai, B.; Miyashiro, L.; Tsutsumi, S.; and Chun, C. 1982b. Hazard analysis of Char siu and roast pork in Chinese restaurants and markets. J. Food Prot. 45: 422-429.

Bryan, F. L.; Harvey, M.; and Misup, M. C. 1981. Hazard analysis of party-pack foods prepared at a catering establishment. J. Food Prot. 44: 118-123.

Bryan, F. L., and Lyon, J. B. 1984. Critical control points of hospital foodservice operations. J. Food Prot. 47: 950-963.

Bryan, F. L., and McKinley, T. W. 1974. Prevention of foodborne illness by time-temperature control of thawing, cooking, chilling and reheating turkeys in school lunch kitchens. J. Milk Food Technol. 37: 420-429.

Bryan, F. L.; Sugi, M.; Miyashiro, L.; Tsutsumi, S.; and Bartleson, C. A. 1982c. Hazard analysis of duck in Chinese restaurants. J. Food Prot. 45: 445-449.

Cichy, R. F.; Nicholas, R. C.; and Zabik, M. E. 1982. An application of the Pareto principle to a critical control point in a commissary foodservice system. Food Technol. 36(9): 8992.

Cook, C. C., and Casey, R. 1979. Assessment of a foodservice management sanitation course. J. Environ. Health. 41: 281-284.

Dahl, J. 1986. You want seconds at the salad bar? Better think it over. The Wall Street J. April 17: 1, 24.

Davies, A. 1968. Control of raw materials. J. Food Technol. 3: 431-436. 
Dunsmore, D. G.; Twomey, A.; Whittlestone, W. G.; and Morgan, H. W. 1981. Design and performance of systems for cleaning product-contact surfaces of food equipment: A review. J. Food Prot. 44: 220-240.

Engelbrecht, R. S.; Weber, M. J.; Salter, B. L.; and Schmidt, C. A. $1980 . \quad$ Comparative inactivation of viruses by chlorine. Appl. Environ. Microbiol. 40: 249-256.

FDA. 1982. AFDO/HHS Retail Food Store Sanitation Code. Washington, D.C.: Food and Drug Administration. U.S. Dept. of Health and Human Services.

Fellers, P. J. and Pflug, I. J. 1967. Storage of pickling cucumbers. Food Technol. 21:74-78.

Finch, J. E.; Prince, J.; and Hawksworth, M. 1978. A bacteriological survey of the domestic environment. J. Appl. Bacteriol. 45: 357-364.

Foegeding, P. M. 1983. Bacterial spore resistance to chlorine compounds. Food Technol. 37(11): 100-104, 110.

Foegeding, P. M.; Hemstapat, V.; and Giesbrecht, F. G. 1986. Chlorine dioxide inactivation of Bacillus and Clostridium spores. J. Food Sci. 51: 197-201.

Gerba, C. P.; Goyal, S. M.; Cech, I.; and Bogdan, G. F. 1980. Bacterial indicators and environmental factors as related to contamination of oysters by enteroviruses. J. Food Prot. 43: 99-101.

Gorman, S. P.; Scott, E. M.; and Hutchinson, E. P. 1984. Hypochlorite effects on spores and spore forms of Bacillus subtilis and on a spore lytic enzyme. J. Appl. Bacteriol. 56: 295-303.

Greer, G. G., and Jeremiah, L. E. 1980. Effect of retail sanitation on the bacterial load and shelf life of beef. J. Food Prot. 43: 277-287.

Greer, G. G.; Jeremiah, L. E.; and Weiss, G. M. 1983. Effects of wholesale and retail contamination on the case life of beef. J. Food Prot. 46: 842-845.

Grubert, G. 1974. "The Membrane Filter Technique for Sterilizing Filtration and for Particle Removal, with Particular Reference to the Removal of Particles from Parenteral Solutions." In International Symposium on Sterilization and Sterility Testing of Biological Sub. stances. R. H. Regamey, F. P. Gallardo, and W. Hennessen, eds. Basel: S. Karger.

Guterbock, W. M.; Blackmer, P. E.; and Duffy, J. 1984. Cleaning the milking system. Vet. Clin. No. Amer. Large Anim. Pract. 6: 377-390.

Guthrie, R. K., and Scovill, M. A. 1984. Recovery of Escherichia coli and Vibrio cholerae from aquatic microcosms. Water Res. 18: 1055-1057.

Harakeh, M., and Butler, M. 1984. Inactivation of human rotavirus, SAll and other enteric viruses in effluent by disinfectants. J. Hyg. Camb. 93: 157-163.

Heid, J. L., and Joslyn, M. A. 1967. Fundamentals of Food Processing Operations: Ingredients, Methods, and Packaging. Westport, Conn.: AVI Publishing Co.

Hood, M. A., and Ness, G. E. $1982 . \quad$ Survival of Vibrio cholerae and Escherichia coli in estuarine water and sediments. Appl. Environ. Microbiol. 43: 578-584.

Hood, M. A.; Ness, G. E.; Rodrick, G. E.; and Blake, N. J. 1983. Distribution of Vibrio cholerae in two Florida estuaries. Microb. Ecol. 9: 65-75.

Hunt, D. A. 1977. "Indicators of Quality for Shellfish Waters." In Bacterial Indicators/ Health Hazards Associated with Water. ASTM STP635. A. W. Hoadley and B. J. Dutka, eds., Philadelphia, Pa.: American Society for Testing and Materials.

Huss, H. H.; Dalsgaard, D.; Hansen, L.; Ladefoged, H.; Pedersen, A.; and Zittan, L. 1974. The influence of hygiene in catch handling on the storage life of iced cod and plaice. J. Food Technol. 9: 213-221.

Ito, K. 1974. Microbiological critical control points in canned foods. Food Technol. 28:(9): $46-48$.

Kauffman, F. L. 1974. How FDA uses HACCP. Food Technol. 28(9): 51, 84.

Kelly, C. A.; Lynch, B.; and McLoughlin, A. J. 1982. The effect of spray washing on the development of bacterial numbers and storage life of lamb carcases. J. Appl. Bacteriol. 53: $335-341$. 
Keswick, B. H.; Satterwhite, T. K.; Johnson, P. C.; DuPont, H. L.; Secor, S. L.; Bitsura, J. A.; Gary, G.W.; and Hoff, J. C. 1985. Inactivation of Norwalk virus in drinking water by chlorine. Appl. Environ. Microbiol. 50: 261-264.

Koopal, L. K. 1985. Physico-chemical aspects of hard-surface cleaning. 1. Soil removal mechanisms. Neth. Milk Dairy J. 39: 127-154.

Kriaa, H.; Arthaud, J. F.; and Fournaud, J. 1985. Contamination and bacterial retention capacity of beef carcasses at the abattoir. J. Appl. Bacteriol. 59: 23-28.

Kulikovsky, A.; Pankratz, H. S.; and Sadoff, H. L. 1975. Ultrastructural and chemical changes in spores of Bacillus cereus after action of disinfectants. J. Appl. Bacteriol. 38: $39-46$.

Larkin, E. P., and Hunt, D. A. 1982. Bivalve mollusks: Control of microbiological contaminants. BioScience 32: 193-197.

Leahy, T.J., and Gabler, R. 1984. Sterile filtration of gases by membrane filters. Biotechnol. Bioeng. 26: 836-843.

McBride, M. E. 1984. Microbial flora of in-use soap products. Appl. Environ. Microbiol. 48: 338-341.

Madden, R. H.; Buller, H.; and McDowell, D. W. 1986. Clostridium perfringens as an indicator of hygienic quality of depurated shellfish. J. Food Prot. 49: 33-36.

Makinde, M. A.; Gilbert, S. G.; and Lachance, P. A. 1976. Nutritional implications of packaging systems. Food Product Develop. 10(7): 112-119.

Middlemiss, N. E.; Nunes, C. A.; Sorensen, J. E.; and Paquette, G. 1985 . Effect of a water rinse and a detergent wash on milkfat and milk protein soils. J. Food Prot. 48: 257-260.

Millipore. 1970. The Scope of Millipore Technology. Catalog No. LTMT 003 BB. Bedford, Mass.: The Millipore Corporation.

Mossel, D. A. A. 1969. Microbiological quality control in the food industry. J. Milk Food Technol. 32: 155-171.

Mulder, R. W. A. W., and Bolder, N. M. 1981. The effect of different bird washers on the microbiological quality of broiler carcasses. Vet. Quart. 3: 124-130.

Munsch, M.; Simard, R. E.; and Girard, J. 1982. Effect of further treatments on the microflora of commercially washed stored carrots. Can. Inst. Food Sci. Technol. J. 15: 322324.

NAS. 1969. An Evaluation of the Salmonella Problem. Pub. No. 1683. Washington, D.C.: National Academy of Sciences.

Notermans, S.; Terbijhe, R. J.; and Van Schothorst, M. 1980. Removing faecal contamination of broilers by spray-cleaning during evisceration. Br. Poultry Sci. 21: 115-121.

O'Brien, R. T., and Newman, J. 1979. Structural and compositional changes associated with chlorine inactivation of polioviruses. Appl. Environ. Microbiol. 38: 1034-1039.

Olson, W. P. 1983. Process microfiltration of plasma proteins. Proc. Biochem. 18(10): 2933.

Pedraja, R. R. 1973. "Current Status of the Sanitary Quality of Fishery Products in the Western Hemisphere." In Microbial Safety of Fishery Products. C. O. Chichester and H. D. Graham, eds. New York and London: Academic Press.

Peterson, A. C., and Gunnerson, R. E. 1974. Microbiological critical control points in frozen foods. Food Technol. 28(9): 37-44.

Powell, M. S., and Slater, N. K. H. 1982. Removal rates of bacterial cells from glass surfaces by fluid shear. Biotechnol. Bioeng. 24: 2527-2537.

Robertson, J. H., and Frieben, W. R. 1984. Microbial validation of vent filters. Biotechnol. Bioeng. 26: 828-835.

Roelants, P.; Boon, B.; and Lhoest, W. 1968. Evaluation of a commercial air filter for removal of viruses from the air. Appl. Microbiol. 16: 1465-1467.

Scott, E.; Bloomfield, S. F.; and Barlow, C. G. 1982. An investigation of microbial contamination in the home. J. Hyg. Camb. 89: 279-293. 
Sheena, A. Z., and Stiles, M. E. 1983. Comparison of barrier creams and germicides for hand hygiene. J. Food Prot. 46: 943-946.

Sheridan, J.J. 1982. Problems associated with commercial lamb washing in Ireland. Meat Sci. 6: 211-219.

Skelley, G. C.; Fandino, G. E.; Haigler, J. H.; and Sherard, R. C., Jr. $1985 . \quad$ Bacteriology and weight loss of pork carcasses treated with a sodium hypochlorite solution. J. Food Prot. 48: 578-581.

Smulders, F. J. M., and Woolthuis, C. H. J. 1985. Immediate and delayed microbiological effects of lactic acid decontamination of calf carcasses-Influence on conventionally boned versus hot-boned and vacuum-packaged cuts. J. Food Prot. 48: 838-847.

Snyder, O. P., Jr. 1986. Microbiological quality assurance in foodservice operations. Food Technol. 40(7): 122-130.

Stanley, P. M. 1983. Factors affecting the irreversible attachment of Pseudomonas aeruginosa to stainless steel. Can. J. Microbiol. 29: 1493-1499.

Stiles, M. E., and Sheena, A. Z. 1985. Efficacy of low-concentration iodophors for germicidal hand washing. J. Hyg. Camb. 94: 269-277.

Stone, J. B.; Myhr, A. N.; and Davie, I. 1983. Effect of low-temperature cleaning of milking equipment on the microbiological quality of raw milk. J. Food Prot. 46: 58-60.

Stone, L. S., and Zottola, E. A. 1985a. Scanning electron microscopy study of stainlesssteel finishes used in food processing equipment. Food Technol. 39(5): 110, 112-114.

1985b. Effect of cleaning and sanitizing on the attachment of Pseudomonas fragi to stainless steel. J. Food Sci. 50: 951-956.

Vaughn, J. M.; Chen, Y.; and Thomas, M. Z. 1986. Inactivation of human and simian rotaviruses by chlorine. Appl. Environ. Microbiol. 51: 391-394.

Vaughn, J. M., and Landry, E. F. 1984. Public health considerations associated with molluscan aquaculture systems: Human viruses. Aquaculture 39: 299-315.

Warne, D.; Capaul, D.; and Moffitt, D. 1985. Aspects of the hazard analysis critical control point (HACCP) concept for the canned food industry. Food Technol. Aust. 37(2): $78-80,83$.

Wei, C.; Cook, D. L.; and Kirk, J. R. 1985. Use of chlorine compounds in the food industry. Food Technol. 39(1): 107-115.

Wheeler, S. M.; Fleet, G. H.; and Ashley, R. J. 1982. The contamination of milk with iodine from iodophors used in milking machine sanitation. J. Sci. Food Agr. 33: 987-995.

WHO. 1969. Recommended International Code of Hygienic Practice for Canned Fruit and Vegetable Products. Secretariat of the Joint FAO/WHO Food Standards Programme, FAO, Rome.

Wlodkowski, T. J., and Rosenkranz, H. S. 1975. Mutagenicity of sodium hypochlorite for Salmonella typhimurium. Mutat. Res. 31: 39-42.

Woolthuis, C. H. J. and Smulders, F. J. M. 1985. Microbial decontamination of calf carcasses by lactic acid sprays. J. Food Prot. 48: 832-837.

Wright, J., and Feun, L. 1986. Food service manager certification: An evaluation of its impact. J. Environ. Health 49: 12-15.

Wright, M. E.; Hoehn, R. C.; Coleman, J. R.; and Brzozowski, J. K. 1979. A comparison of single use and recycled water leafy vegetable washing systems. J. Food Sci. 44: 381$389,391$.

Wyatt, C. J. 1979. Concerns, experiences, attitudes and practices of food market managers regarding sanitation and safe food handling procedures. J. Food Prot. 42: 555-560.

Wyatt, C. J., and Guy, V. 1980. Relationships of microbial quality of retail meat samples and sanitary conditions. J. Food Prot. 43: 385-389.

Wyatt, L. R., and Waites, W. M. 1975. The effect of chlorine on spores of Clostridium bifermentans, Bacillus subtilis and Bacillus cereus. J. Gen. Microbiol. 89: 337-344. 